\title{
A gazdasági és társadalmi fejlődés elősegíti-e az emberek elégedettségének és boldogságának növekedését Kínában?
}

Egy társadalom elégedettsége mindig fontos „mutatója”egy ország müködésének, többek között gazdasági és politikai szempontból is. Az, hogy menynyire beszélhetünk egészséges társadalmi fejlődésröl, mekkora a társadalomnak az a rétege, amely elégedetlen a sorsa alakulásával, esetleg kilátástalannak látja a maga és családja életének alakulását a jövőben, fontos visszajelzés lehet a döntéshozók számára a múltban és jelenben hozott döntéseik hatásának következményeiröl. A tanulmány egy 2015-ben végzett empirikus kutatás ${ }^{1}$ eredményeiböl indul ki, és megpróbál következtetéseket levonni - a kínai kormány munkájának teljesítményével való elégedettség mutatóiból, a boldogság, az elégedettség indikátorainak elemzéséből - arra vonatkozóan, hogy a kínai közemberek szubjektív jóléte - elégedettsége, boldogsága - menynyiben járul hozzá a kormányzati rendszer hosszú távú stabilitásához, Kína sajátos politikai rendszerének zavartalan müködéséhez.

\section{Bevezetés}

Érdemes egy rövid pillantást vetni a korai kilencvenes években bevezetett gazdasági reformok társadalmi hatására. A késő 1990-es évekre privatizálják a kis- és közepes méretü állami vállalatokat, majd 1992-től a privatizáció felgyorsításával megszabadulnak az állandó veszteséget termeló állami vállalatoktól. ${ }^{2}$ A stratégiailag kulcsfontosságú (energia, közlekedés, telekommunikáció, biztonságpolitika stb.) iparágak kivételével az állami tulajdonú vállalatok tulajdonát Jiang Zemin 江泽民 (államelnök 1993-2003) és Zhu

\footnotetext{
12015 januárjában egyhónapos pilot study kutatást végeztem Qinhuangdaóban 秦皇岛 (Hebei 河北 tartomány). A minta 108 fös volt.

2 Pei 2008: 10.
} 
Rongji 朱F基 (miniszterelnök 1998-2003) kormányzása időszaka alatt privát befektetőknek adják el.

Az állami tulajdonú vállalatok megszüntetésével és privatizációjával az állami vállalatoktól elbocsátottak száma növekszik. 1993-ban 30 millió állami alkalmazott válik munkanélkülivé, ${ }^{3}$ majd 1996-tól a további csökkentések eredményeként 2003-ig több mint 28 millió állami alkalmazottól válnak meg. ${ }^{4}$

1988-ban a politika hivatalossá teszi, hogy a sajátosan kínai színezetü szocialista társadalom építésében a privatizáció kiegészítő szerepet tölt be, majd 1999-től a magángazdaságra már úgy hivatkoznak, mint a gazdaság egyik fó építőelemére. A privát vállalkozások legalizálása a munkanélküliség csökkentésében óriási szerepet játszott.

A munkaerőpiac stabil müködése érdekében liberalizálják a hukou rendszert, enyhítik a városi hukouhoz való hozzájutás szigorú szabályait.

A városi lakásrendszer 1994-ben meghirdetett reformjával lehetővé teszik azt, hogy a megvásárolt lakásokat öt év türelmi idő után a tulajdonosok értékesítsék. A reformoknak köszönhetően a Hu Jintao 胡锦涛 (államelnök 2003-2013) és Wen Jiabao 温家宝 (miniszterelnök 2003-2013) neve fémjelezte adminisztráció időszakára az ingatlanpiaci árak megháromszorozódnak. Az ingatlannal kapcsolatos reformok bevezetése elsősorban a városi lakosságot hozta kedvező helyzetbe.

A korai kilencvenes években a tulajdonosi középosztály kialakulása, vagyona, befektetései és vásárlóereje a társadalmi, politikai és kulturális változások egyik jelentős következménye, egyértelmúen ők a gazdasági növekedés és fejlödés anyagi nyertesei.

2013-ban a Kínai Kommunista Párt 18. Központi Bizottságának harmadik plénuma, az egyenlőtlenségek (a Gini-index 0,473 volt ekkor) felszámolását tüzi ki célul. A társadalmi stabilitás megörzése érdekében 2020-ra kívánják elérni azt, hogy a kínai lakosság 60\%-a városokban lakjon. Ez körülbelül 260 millió vidéki lakos városba költöztetését jelenti, 150 millió új munkahely létrehozását, és körülbelül 150 millió már városban lakó migráns közegészségügyhöz, közoktatáshoz és szociális ellátórendszerhez való könynyebb hozzáférésének biztosítását. ${ }^{5}$

\footnotetext{
Naughton 2006: 184.

Naughton 2006: 186.

Shambaugh 2014.
} 
A „mérsékelten jómódú társadalom” (xiaokang shehui 小康社会) megteremtése 2021-re azt a célt tüzi ki, hogy a társadalom valamennyi rétege számára „szerény jólétet” garantál, és mérsékli a társadalmi egyenlőtlenségeket.

Az 1980-as évektől 2005-ig a GDP átlagos éves növekedése 10\% volt, 2003-ban az egy före eső GDP elérte a 4726 dollárt. $^{6}$ Világviszonylatban óriási teljesítmény volt az, hogy az elmúlt negyedszázadban Kína egy före jutó reál GDP-je több mint ötszörösére nőtt. ${ }^{7}$

\section{A kínai emberek elégedettségét és boldogságát mérő kutatások}

Annak ellenére, hogy a boldogsággal foglalkozó szakirodalom egyre inkább bővül, a kínai emberek saját életükkel való elégedettségének mérésével viszonylag kevés tanulmány foglalkozik. ${ }^{8} \mathrm{Ji}$, Xu és Rich Shanghai 上海 és Tianjin 天津 városában mérte a kínai városi lakosság elégedettségi szintjét. ${ }^{9}$ A kínai emberek szubjektív jólétét az 1990-ben, 1995-ben, 2000-ben és 2007ben folytatott World Values Survey vizsgálatok mérték. A 2007-es kutatás arra az eredményre jutott, hogy a kínaiak az 1990 és 1995 közötti időszakban boldogabbak voltak és az élettel való elégedettségük 1990-ben magasabb volt, mint 2007-ben. Az 1995 és 2000 közötti időszakban jelentős visszaesés következett be. ${ }^{10}$

A vizsgálatokban a jövedelmek emelkedése közvetlen szerepet játszott az élettel való elégedettség növekedésében. A saját lakástulajdon megszerzése is emelte az élettel való elégedettséget. A jövedelem mellett a társadalmi pozícióval való elégedettség szintén növelte az élettel való általános elégedettséget. ${ }^{11}$ Kevésbé voltak elégedettek az alapvető élelmiszerek árával és a tömegközlekedés helyzetével, de ennek ellenére a kormány munkájával általában elégedettek voltak.

A World Values Survey-hez hasonló eredményre jutott Brockman is, ${ }^{12}$ aki azt állapította meg, hogy az 1990 és 2000 közötti időszakban az emberek

\footnotetext{
Naughton 2006: 1.

Itoh 1997.

Song - Appleton 2008.

Ji, Xu - Rich 2002.

Song - Appleton 2008: 6.

Steele - Scott 2014.

Brockman 2009.
} 
saját életükkel való elégedettségének átlaga csökkent. Brockman a kínai átmenet egyik legjellemzőbb sajátosságának azt tartja, hogy sok ember pénzügyi helyzete relatívan javult, nőtt az egyenlőtlenség a társadalomban, viszont ezzel nem járt együtt az emberek saját életükkel való elégedettségének emelkedése. ${ }^{13}$ Amíg ezalatt az időszak alatt a boldogság átlagértéke növekedett, addig a kínaiak elégedettsége a saját életükkel kapcsolatban csökkent.

Vizsgálati anyagom eredményei is ezt a kutatási eredményt támasztják alá, miszerint a boldogság átlagértéke 2015-ben magasabb volt, mint az elégedettség átlagértéke.

A szubjektív jólét két legfontosabb indexe az elégedettség és a boldogság. Egyéni kutatásom eredményeinek bemutatásával először az elégedettségről, majd a boldogságról, vagyis a szubjektív jólét két indexéről teszek állításokat, illetve a kínai mintában kapott adatokat hasonlítom össze a European Social Survey (ESS) adataival.

\section{Elégedettség}

Pilot-study kutatásomban a kínaiak elégedettségét hat területen vizsgáltam. Az elégedettséggel kapcsolatban hat kérdést tettem fel, ezek közül egy vonatkozott a megkérdezettek egyéni életére, a többi öt kérdés pedig a társadalom különböző területeire. (I.1. táblázat)

\begin{tabular}{||l|c|c|c||}
\hline \multicolumn{1}{|c|}{$\begin{array}{c}\text { Mindent összevetve } \\
\text { mennyire elégedett? }\end{array}$} & $\begin{array}{c}\text { Kína } \\
\mathbf{2 0 1 5} \text { év átlag* }\end{array}$ & $\begin{array}{c}\text { Magyarország } \\
\mathbf{2 0 1 2} / \mathbf{1 3} \text { év átlag }\end{array}$ & $\begin{array}{c}\text { Európa } \\
\mathbf{2 0 1 2} / \mathbf{1 3} \text { év átlag }\end{array}$ \\
\hline \hline Mostani életével & 6,72 & 5,59 & 6,82 \\
\hline A gazdaság állapotával & 5,85 & 3,35 & 4,05 \\
\hline A kormány munkájával & 5,73 & 3,61 & 3,99 \\
\hline A demokrácia müködésével & 5,51 & 4,50 & 5,20 \\
\hline Az oktatás állapotával & 4,82 & 4,73 & 5,58 \\
\hline Az egészségügy állapotával & 4,48 & 3,94 & 5,18 \\
\hline Elégedettség átlag & $\mathbf{5 , 5 2}$ & $\mathbf{4 , 4 1}$ & $\mathbf{5 , 2 5}$ \\
\hline
\end{tabular}

I.1. táblázat Mindent összevetve mennyire elégedett...?

13 Brockman 2009.

* Átlag. A mérésnél egy tizenegy fokú létrát alkalmaztam, ahol a 0 érték jelentette a teljesen elégedetlent, a 10 pedig a teljesen elégedettet. 
A kínai mintában kapott eredményeket összehasonlítottam a meglévő magyarországi és európai adatokkal. Az összehasonlítás alapján összességében azt lehet elmondani, hogy mind a három régióban az emberek a saját életükkel sokkal elégedettebbek, mint az országéval, annak demokráciájával, a kormány munkájával és gazdasági állapotával. Magyarországon a tizenegy fokú elégedettség létrán a létra közepénél eggyel nagyobb létrafokra sem jutottak el átlagosan (átlag=4,41 a 0-tól 10 fokig terjedő létrán). Lesújtó az emberek véleménye Magyarország gazdasági állapotáról (az átlagérték 3,35 súlyozott számtani átlag -, de a másik két középérték, a medián - középső érték, ugyanannyian vannak elégedetlenebbek, mint amennyien elégedettebbek -, és a módusz - a leggyakrabban választott érték - is a 3-as létrafokon állt). (I.1. ábra)

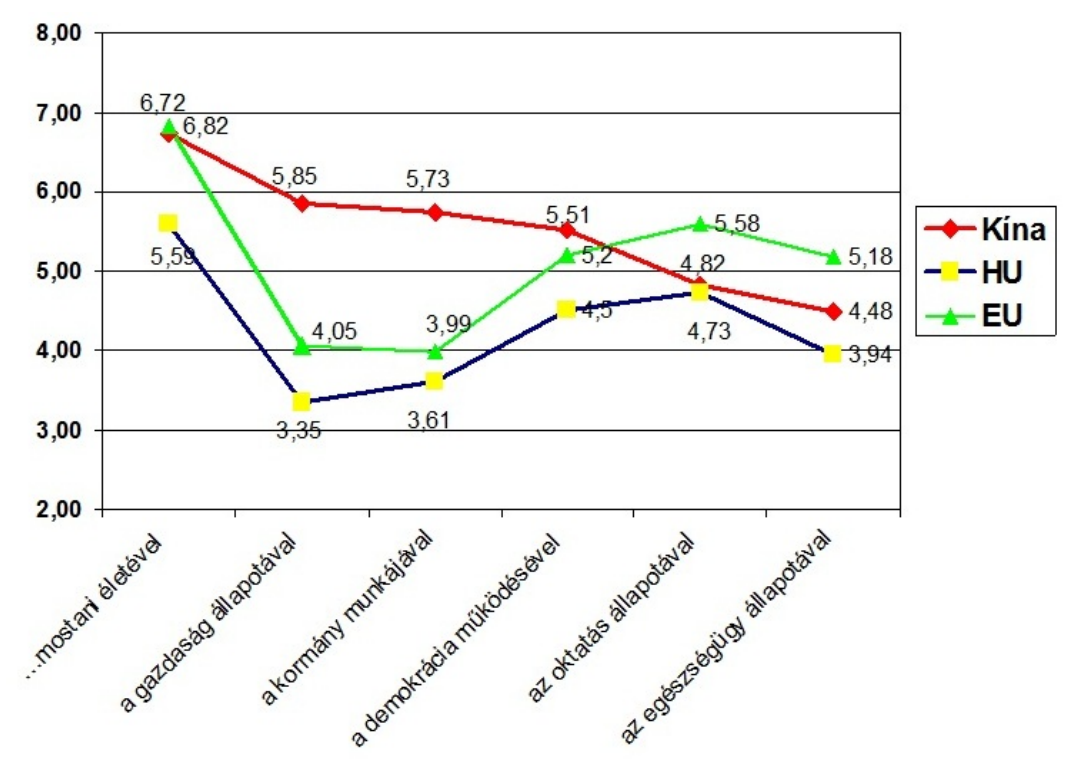

I.1. ábra Kina, Magyarország és Európa elégedettsége hat területen

Kínai kísérleti kutatásom eredményei azt mutatják, hogy Kínában a megkérdezettek az oktatás és az egészségügy állapotával elégedetlenebbek csak (a hibahatáron belül van a különbség a mostani életükkel kapcsolatos elégedettséggel), mint európai társaik, de elégedettebbek, mint a magyarok. Lényegesen elégedettebbek a kínaiak országuk gazdasági állapotával és kormányuk munkájával. 
Összefoglalóan azt mondhatom, hogy

1) minden vizsgált országban a megkérdezetteknek a mostani életükkel való elégedettsége a legmagasabb;

2) minden vizsgált országban a megkérdezettek a jelenlegi életükkel való elégedettségük szerint ítélik meg az országot;

3) a kínai mintában a megkérdezettek mostani életükkel elégedettebbek, mint a magyarok (a különbség 1,13, vagyis több mint egy létrafok), és az európai átlagot is hibahatáron belül elérik;

4) a kínai vizsgált személyek különösen kormányuk munkájával elégedettebbek, mint európai társaik (a magyarokénál 2,12, az európai átlagnál 1,74 a különbség a javukra);

5) a vizsgált kínai személyek átlagos elégedettsége is jelentősen magasabb $(5,52)$ a magyarokénál 1,1-del (egy lépcsőfokkal), de az európaiak átlagánál is 0,27 -tel.

\section{I.1. Az elégedettség tere}

A hat területre vonatkozó elégedettség a kísérleti kínai minta 103 dimenziós terében a következő konfigurációt mutatja a legkisebb térelemzés kétdimenziós terében. (I.2. ábra)

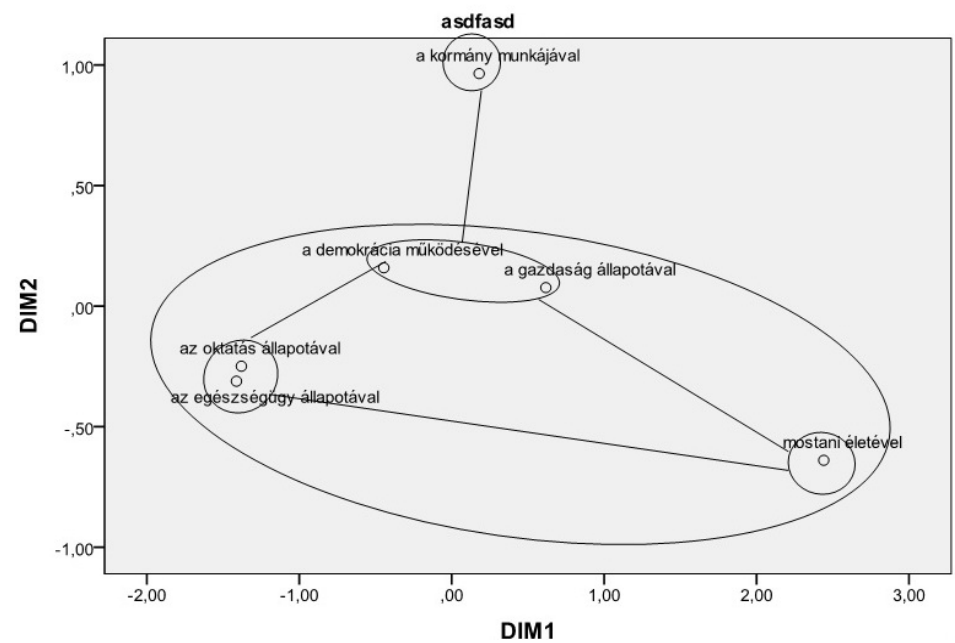

I.2. ábra Elégedettség tér Kínában, 2015 , Mindent összevetve mennyire elégedett... ? MDS ALSCAL modell 
A kínai elégedettség terét a megkérdezettek mostani életével való elégedettség, a kínai kormánnyal való elégedettség, illetve az egészségügy és az oktatás állapotával (ezzel a kettővel a legelégedetlenebbek) három sarokpontja feszíti ki, amely sajátos alakot mutat, belül egy ún. „ördögkerék” forog (mint Magyarországon a búsójáráson használt szekér Mohácson), amelynek van egy mozgásban lévő forgó kör/ellipszis aljzata, s amelyet a kormányrúd mozgat, ami mutatja a haladás irányát és sebességét.

A lenti két ábrán az európai és a magyarországi elégedettség tere jól mutatja, hogy az emberek másként élik meg a saját életüket és azokat a területeket, ahol közvetlenül vannak kapcsolatban a társadalommal (egészségügy, oktatás), illetve a rájuk közvetetten ható, a kormányzással szorosan összefüggő, a kormány munkájával, a gazdaság állapotával és a demokrácia müködésével kapcsolatos területeket. Ez a három terület jól elkülönül egymástól, bizonyos szembenállást is mutat (az egyikkel elégedettek nem feltétlenül elégedettek a szembenálló területtel), egy háromszög három csúcspontjaként. Európa 29 országában együttesen nagyon hasonló, lényegében a magyarokéval megegyező konfigurációt mutat az elégedettség tere. (I.3. és I.4. ábra)

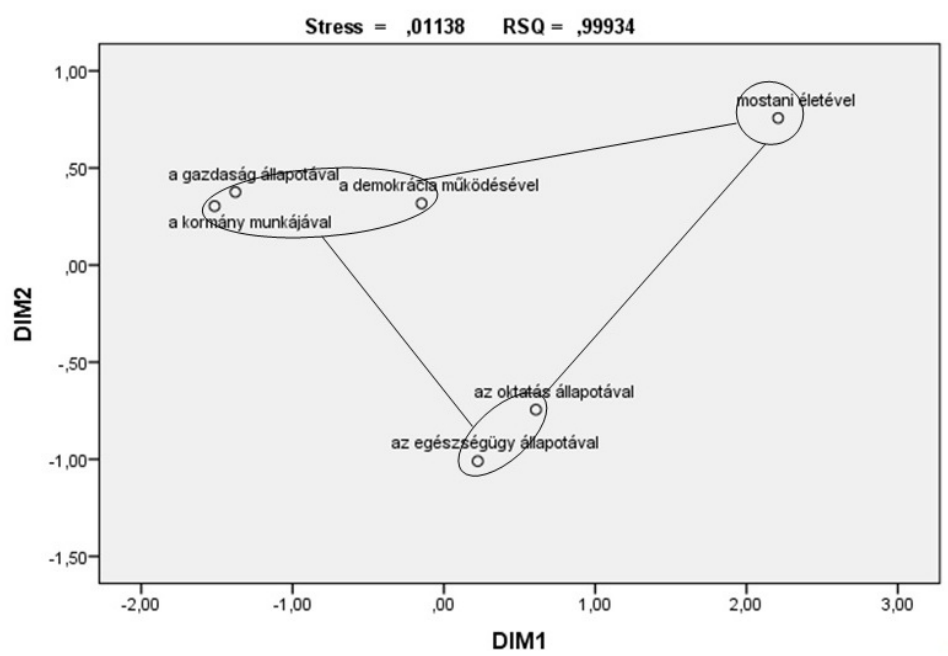

I.3. ábra Elégedettség tér Európában, 2012/13 ALSCAL modell 


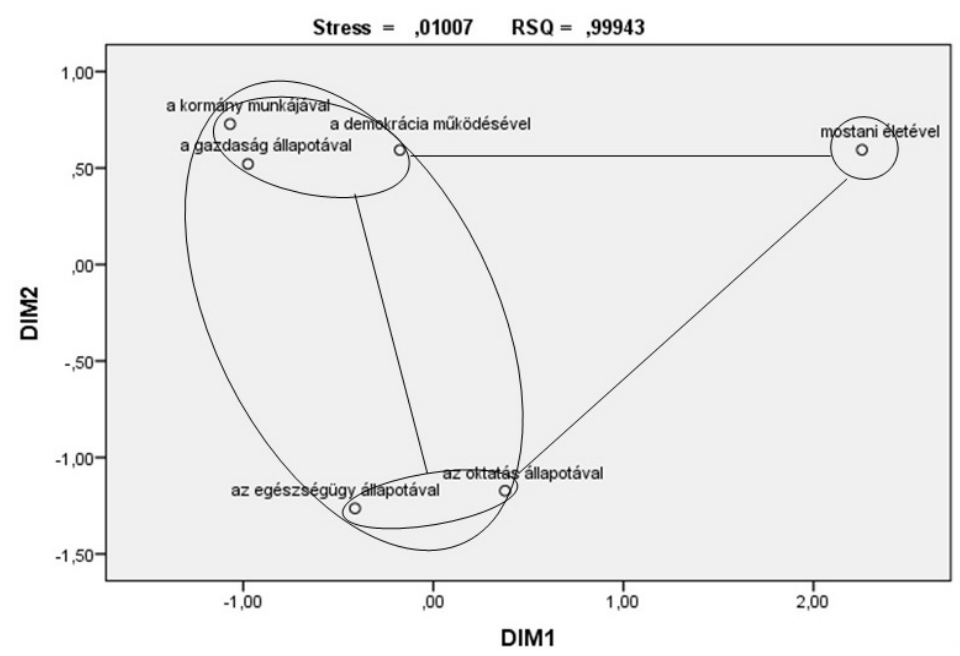

I.4. ábra Elégedettség tér Magyarország, 2012/13

INDSCAL modell

\section{I.2. Elégedettség indikátor}

Az elégedettség indikátort (EI) a hat területre vonatkozó elégedettségnek várható értékével (átlag) fejeztem ki. (I.2. táblázat)

Míg Magyarország 2002-ben a vizsgált 22 ország között az elégedettség indikátor szerint a 15 . helyen volt (a sorrend 68,2\%-os szintjén), addig 2012/13-ban a 21. helyet foglaltuk el az elégedettség indikátor szerinti sorrendben 29 ország között (ez a sorrend 72,4\%-os helye, vagyis az országok elégedettségi sorrendjében kicsit visszacsúsztunk). A volt szocialista országok közül hatan is megelőztek bennünket 2012/13-ban. Mögöttünk a válsággal küzdő dél-európai országok (Olaszország, Spanyolország, Portugália) és a volt szocialista blokk egyes ortodox vagy muszlim országai (Oroszország, Koszovó, Albánia, Ukrajna és Bulgária) találhatók. Ha azonban csak a saját élettel való elégedettség mutatóját nézzük, a magyarok mögött csupán két országot látunk, Ukrajnát és Bulgáriát. A „legvidámabb barakkból” a „legelégedetlenebb szabad nemzet" lettünk 2012/13-ra. ${ }^{14}$

14 Füstös-Tárnok 2013. 


\begin{tabular}{|c|c|c|c|c|c|c|c|c|}
\hline \multicolumn{9}{|c|}{ Mindent egybevetve mennyire elégedett... } \\
\hline s.sz. & Országok & $\begin{array}{l}\text { Jelenlegi } \\
\text { életével }\end{array}$ & $\begin{array}{c}\text { Az ország gazdasági } \\
\text { állapotával }\end{array}$ & $\begin{array}{l}\text { A kormány } \\
\text { munkájával }\end{array}$ & $\begin{array}{l}\text { A demokrácia } \\
\text { müködésével }\end{array}$ & $\begin{array}{l}\text { Az oktatás } \\
\text { állapotával }\end{array}$ & $\begin{array}{c}\text { Az egészségügy } \\
\text { alllapotával }\end{array}$ & $\begin{array}{l}\text { Elégedettségi } \\
\text { indikátor }\end{array}$ \\
\hline 1. & Svájc & 8,19 & 7,01 & 6,60 & 7,39 & 7,12 & 7,21 & 7,35 \\
\hline 2. & Norvégia & 8,14 & 7,98 & 5,85 & 7,24 & 6,91 & 6,46 & 7,17 \\
\hline 3. & Finnország & 8,11 & 6,01 & 5,86 & 6,85 & 8,03 & 6,86 & 7,06 \\
\hline 4. & Dánia & 8,57 & 5,55 & 4,80 & 7,34 & 7,83 & 6,94 & 6,93 \\
\hline 5. & Svédország & 7,87 & 6,11 & 5,60 & 7,01 & 5,76 & 6,30 & 6,53 \\
\hline 6. & Belgium & 7,44 & 4,97 & 5,08 & 5,86 & 6,80 & 7,68 & 6,39 \\
\hline 7. & Hollandia & 7,90 & 5,18 & 5,13 & 6,31 & 6,20 & 6,51 & 6,32 \\
\hline 8. & Németország & 7,60 & 5,88 & 4,86 & 6,16 & 5,20 & 5,80 & 6,00 \\
\hline 9. & Izrael & 7,52 & 4,60 & 4,43 & 5,91 & 5,12 & 6,48 & 5,75 \\
\hline 10. & Izland & 7,97 & 3,87 & 3,68 & 5,73 & 6,89 & 5,59 & 5,70 \\
\hline 11. & Egyesült Királyság & 7,35 & 3,78 & 4,04 & 5,58 & 5,88 & 6,26 & 5,57 \\
\hline 12. & Kína & 6,72 & 5,73 & 5,85 & 5,51 & 4,82 & 4,48 & 5,52 \\
\hline 13. & Csehország & 6,67 & 3,87 & 3,57 & 5,04 & 6,17 & 5,52 & 5,26 \\
\hline 14. & Észtország & 6,18 & 4,11 & 3,87 & 4,89 & 5,93 & 5,03 & 5,12 \\
\hline 15. & Litvánia & 5,99 & 4,03 & 4,25 & 5,02 & 5,49 & 4,93 & 5,05 \\
\hline 16. & Franciaország & 6,53 & 3,17 & 3,51 & 5,10 & 5,31 & 6,41 & 5,09 \\
\hline 17. & Szlovákia & 6,76 & 3,65 & 3,98 & 5,00 & 5,32 & 4,05 & 4,88 \\
\hline 18. & Irország & 6,78 & 2,85 & 3,34 & 5,47 & 6,13 & 4,13 & 4,84 \\
\hline 19. & Lengyelország & 7,12 & 4,20 & 3,39 & 4,91 & 5,25 & 3,45 & 4,79 \\
\hline 20. & Ciprus & 6,86 & 2,13 & 3,26 & 4,88 & 5,53 & 5,05 & 4,62 \\
\hline 21. & Szlovénia & 6,98 & 2,56 & 2,58 & 3,61 & 5,39 & 5,64 & 4,54 \\
\hline 22. & Magyarország & 5,59 & 3,35 & 3,61 & 4,50 & 4,73 & 3,94 & 4,41 \\
\hline 23. & Olaszország & 6,68 & 2,66 & 2,80 & 4,11 & 4,90 & 4,93 & 4,43 \\
\hline 24. & Oroszországi Föd. & 5,80 & 3,75 & 4,25 & 3,82 & 3,99 & 3,42 & 4,27 \\
\hline 25. & Spanyolország & 6,91 & 2,16 & 2,51 & 3,98 & 4,54 & 5,24 & 4,30 \\
\hline 26. & Koszovó & 6,18 & 2,78 & 3,15 & 4,00 & 5,14 & 3,30 & 4,16 \\
\hline 27. & Albánia & 5,72 & 3,14 & 3,15 & 3,72 & 4,79 & 3,91 & 4,12 \\
\hline 28. & Portugália & 5,99 & 2,09 & 2,15 & 3,90 & 4,44 & 4,06 & 3,88 \\
\hline 29. & Ukrajna & 5,15 & 2,71 & 2,51 & 3,33 & 4,30 & 2,90 & 3,55 \\
\hline 30. & Bulgária & 4,42 & 1,96 & 2,74 & 3,10 & 3,97 & 2,86 & 3,29 \\
\hline \multicolumn{2}{|c|}{ EU átlag } & 6,82 & 4,05 & 3,99 & 5,20 & 5,58 & 5,18 & 5,25 \\
\hline
\end{tabular}

I.2. táblázat Elégedettség Európában 2012/13-ban "és Kinában 2015-ben

A kínai kísérleti minta adatai alapján Kína a 12. helyet foglalná el az elégedettség indikátor szerinti sorrendben. Amennyiben a három régiót hasonlítom össze, úgy a kínaiak saját kormányukkal a legelégedettebbek, de elökelő helyen ítélik meg országuk gazdasági állapotát is. Az egészségügy és az oktatás állapotával a legkevésbé elégedettek, és ez a sorrenden meg is látszik, ezen a két területen az utolsó harmadban helyezkednek el. (I.3. táblázat)

\begin{tabular}{||l|c|c|c|c|c|c|c||}
\hline \hline & $\begin{array}{c}\text { Mindent egybevetenlegi } \\
\text { életével }\end{array}$ & $\begin{array}{c}\text { Az ország } \\
\text { gazdasági } \\
\text { âllapotával }\end{array}$ & $\begin{array}{c}\text { A kormány } \\
\text { munkájával }\end{array}$ & $\begin{array}{c}\text { A demokrácia } \\
\text { müködésével }\end{array}$ & $\begin{array}{c}\text { Az oktatás } \\
\text { allapotával }\end{array}$ & $\begin{array}{c}\text { Az egészségügy } \\
\text { allapotával }\end{array}$ & $\begin{array}{c}\text { Elégedettségi } \\
\text { indikátor }\end{array}$ \\
\hline Elsö a sorrendben & Dánia & Norvégia & Svájc & Svájc & Finnország & Belgium & Svájc \\
\hline $\begin{array}{l}\text { Magyarország } \\
\text { helye a sorrendben }\end{array}$ & 28 & 19 & 17 & 21 & 25 & 24 & 23 \\
\hline $\begin{array}{l}\text { Kína helye a } \\
\text { sorrendben }\end{array}$ & 18 & 6 & 4 & 12 & 23 & 20 & 12 \\
\hline
\end{tabular}

I.3. táblázat A legelégedettebb országok Európában, Magyarország (2012/13) és Kina (2015) helye az országok között

Az EI Indikátor szerinti sorrendben 


\section{I.3. Országok az elégedettség terében}

Amennyiben az országokat az elégedettség hat mutatója által kifeszített hatdimenziós mintatérből a látens kétdimenziós térbe konvergáljuk, akkor az alábbi konfigurációt kapjuk. (I.6. ábra)

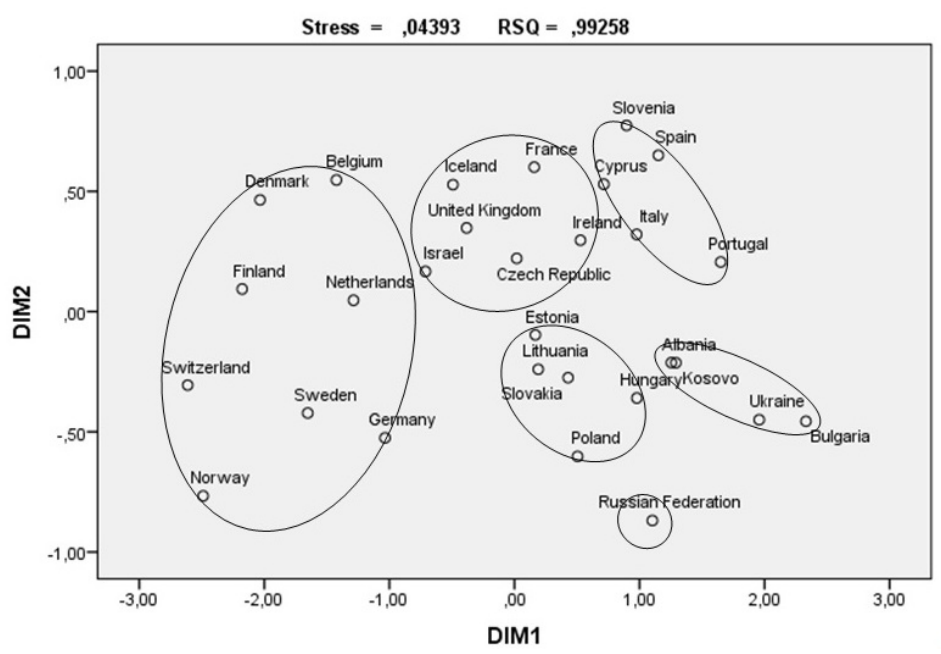

I.6. ábra Országok az Elégedettség térben, 2012/13 ALSCAL modell

Az elégedettség terének bal oldalán találjuk a legelégedettebb nyolc országot. A tér közepe tájékán tíz ország helyezkedik el, ők a közepesen elégedett országok csoportja (az elégedettség sorrend 9-19. helyezettje). Magyarország, Lengyelország, Szlovákia, Litvánia Észtországgal alkot egy csoportot a közepes elégedettségú csapat végén kullogva. Ukrajna és Bulgária a két sereghajtó ország.

Amennyiben Kínát is belehelyezem Európa elégedettség terébe, a következő eredményt kapom. (I.7. ábra)

Kína az elégedettség indikátor szerinti 12. helyezésével a nagyon elégedett és a közepesen elégedett országok térrészének közepén helyezkedik el, de nem közéjük ékelődve a meglehetősen szélsőséges sorrendi helyzetének köszönhetően (a hat elégedettség rangsorbeli helye: 18, 6, 4, 12, 23, 20). 


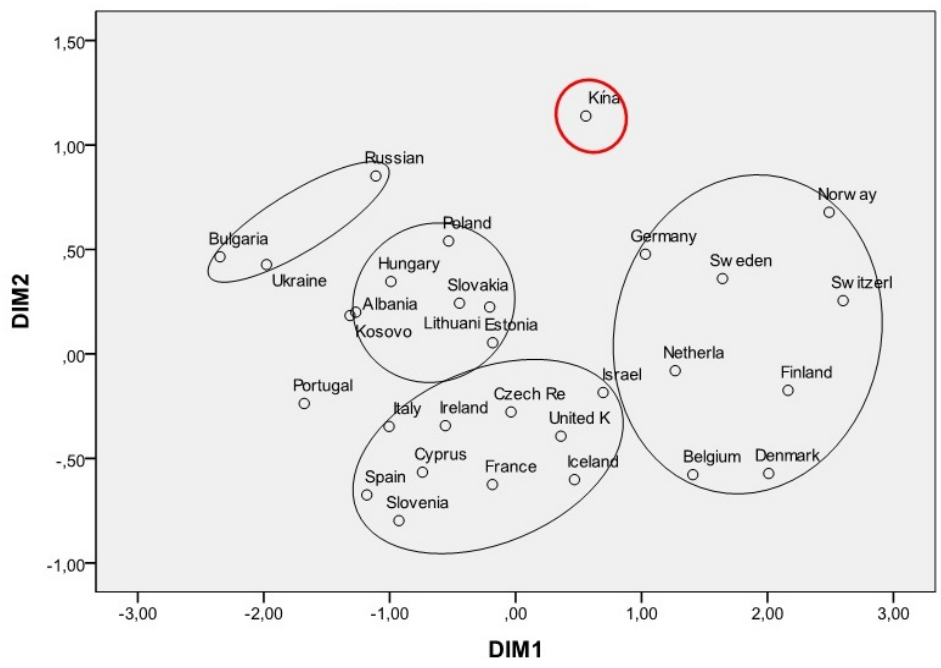

I. 7. ábra Országok az elégedettség térben ALSCAL modell

\section{Boldogság}

A jelenlegi kutatások a kínai emberek boldogságának vizsgálatával kapcsolatban nagyon árnyalt képet mutatnak. Jagodzinski azt írja, hogy mind Európában, mind Ázsiában a boldogságot leginkább a megkérdezettek nemzeti büszkesége változó magyarázza. ${ }^{15}$ Ez országok szintjére levetítve Ázsiában azt jelenti, hogy a nemzeti büszkeség csökkenése az elégedetlenséggel kapcsolódik össze. Inglehart et al. azt állapította meg, hogy a boldogság a közösségi értékekkel függ össze, a szolidaritással, a vallásossággal és a nemzeti büszkeséggel. ${ }^{16} \mathrm{~A}$ kevésbé fejlett országokban a boldogság szorosabb kapcsolatban áll a közösségi értékekkel, mint a fejlettebb országokban. A boldogság a szegényebb országokban a közösségi értékekkel, míg a gazdagabb országokban a szabadsággal van összefüggésben. Tehát a fejlettebb országokban a szabadság fontossága magyarázza inkább a boldogságot.

A boldogság indikátorával kapcsolatban a következő kérdést tettem fel kínai kísérleti mintám megkérdezettjeinek: „Mindent egybevetve, mennyire érzi magát boldognak" (Ez a kérdés szintén szerepelt az ESS/EUTE kérdöívben). Az eredményeket az alábbi táblázat tartalmazza:

15 Jagodzinski 2010.

16 Inglehart et al. 2008. 


\begin{tabular}{||l|c||}
\hline Mindent egybevetve, mennyire érzi magát boldognak? & átlag* \\
\hline Kína & 7,32 \\
\hline Európa & 7,17 \\
\hline Magyarország & 6,10 \\
\hline
\end{tabular}

\section{II.1. táblázat}

* Átlag. A tizenegy fokú létrán a 0: nagyon boldogtalan, 10: nagyon boldog

A kínai mintába bekerült emberek boldogabbak átlagosan, mint európai társaik. A magyarok jelentősen boldogtalanabbak az európai átlagnál.

Az ESS 6. hullámában szereplő országok és kínai mintám adatait találhatjuk a következő táblázatban:

\begin{tabular}{|c|c|c|}
\hline Sorszám & Ország & Átlag \\
\hline 1. & Dánia & 8,38 \\
\hline 2. & Izland & 8,21 \\
\hline 3. & Norvégia & 8,16 \\
\hline 4. & Finnország & 8,09 \\
\hline 5. & Svájc & 8,08 \\
\hline 6. & Hollandia & 7,95 \\
\hline 7. & Izrael & 7,84 \\
\hline 8. & Svédország & 7,82 \\
\hline 9. & Németország & 7,71 \\
\hline 10. & Belgium & 7,69 \\
\hline 11. & Spanyolország & 7,59 \\
\hline 12. & Egyesült Királyság & 7,56 \\
\hline 13. & Lengyelország & 7,33 \\
\hline 14. & Kina & 7,32 \\
\hline 15. & Franciaország & 7,29 \\
\hline 16. & Szlovénia & 7,26 \\
\hline 17. & Ciprus & 7,23 \\
\hline 18. & Írország & 7,13 \\
\hline 19. & Olaszország & 7,09 \\
\hline 20. & Szlovákia & 6,89 \\
\hline 21. & Észtország & 6,82 \\
\hline 22. & Csehország & 6,77 \\
\hline 23. & Litvánia & 6,56 \\
\hline 24. & Albánia & 6,49 \\
\hline 25. & Portugália & 6,49 \\
\hline 26. & Koszovó & 6,39 \\
\hline 27. & Oroszországi Föderáció & 6,29 \\
\hline 28. & Ukrajna & 6,21 \\
\hline 29. & Magyarország & 6,10 \\
\hline 30. & Bulgária & 5,41 \\
\hline \multicolumn{2}{|c|}{ Európa átlaga } & 7,17 \\
\hline
\end{tabular}

II.2. táblázat 
Kínai mintámban az emberek boldogabbak, mint az európai átlagos boldogság, s az európai rangsorban a 14. helyet foglalnák el.

Magyarország boldogságát csupán Bulgária tudja alulmúlni, vagyis igazolódni látszik az, hogy a „legvidámabb barakkból” a „legelégedetlenebb és legboldogtalanabb szabad nemzet" lettünk 2012/13-ra.

\section{II.1. Elégedettség és boldogság}

A következőkben azt mutatom be, hogy a boldogság hogyan függ össze az elégedettséggel.

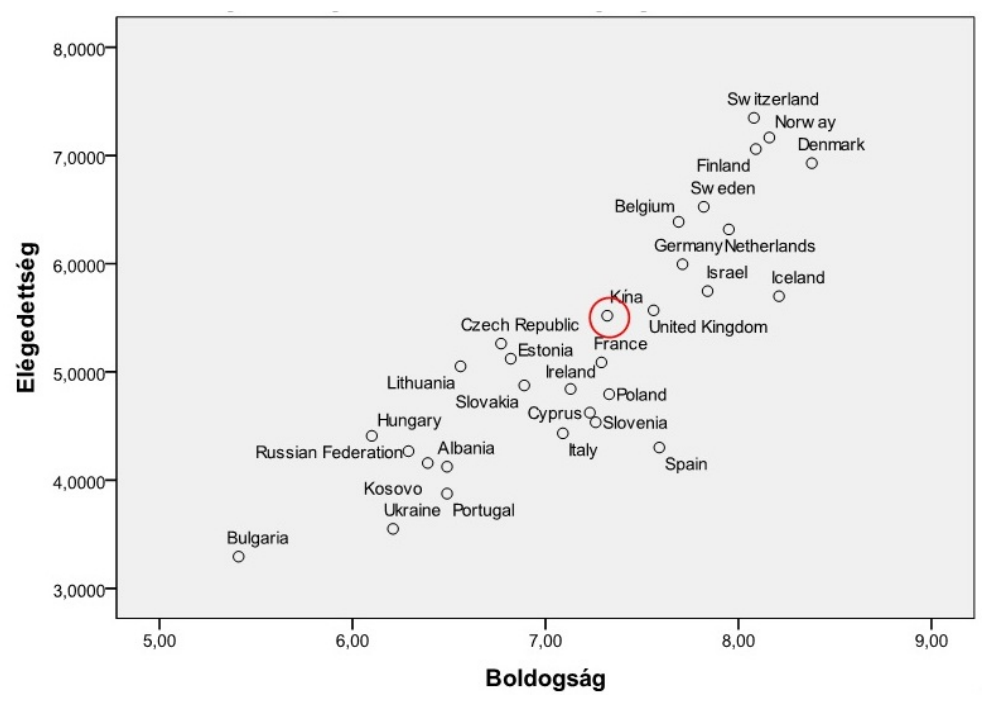

II.1. ábra Elégedettség és Boldogság

Elégedettség Indikátor és a Boldogság kapcsolata

A pontábrán az látható, hogy a boldogság és az elégedettség exponenciális $\left(y=e^{x}\right)$ kapcsolatot mutat (a boldogság növekedésénél a lineárisnál gyorsabban nő az elégedettség).A boldogság független változó az Elégedettség Indikátora varianciájának 76\%-át magyarázza az exponenciális modellben (a lineáris modellben ez 73,9\%)!

Ezt úgy lehet értelmezni, hogy minél boldogabb egy ország lakossága, annál elégedettebb is. 


\section{Easterlin-paradoxon}

Richard Easterlin az 1970-es évek közepén hívta fel a figyelmet arra, hogy az egymást követö nemzedékek általában tehetősebbek, gazdagabbak, mint a szüleik vagy a nagyszüleik, azonban úgy tünik, hogy nincs boldogabb életük, nem boldogabbak náluk. ${ }^{17}$

Az Easterlin-paradoxon kérdése, hogy vajon boldogabbak és elégedettebbek vagyunk-e az életszínvonalunk emelkedésével.

1) Egy társadalomban a gazdag emberek általában sokkal boldogabbak, mint a szegények.

2) De a gazdag társadalmak általában nem lehetnek boldogabbak, mint a szegény társadalmak (vagy nem sokkal).

3) Ahogy az országok gazdagabbak lesznek, nem lesznek boldogabbak.

Easterlin azzal érvelt, hogy az élettel való elégedettség együtt emelkedik az átlagos jövedelemmel, de csak egy bizonyos pontig. A továbbiakban az elégedettség és a boldogság mutatókat hasonlítom össze a GDP-vel. (II.2. ábra)

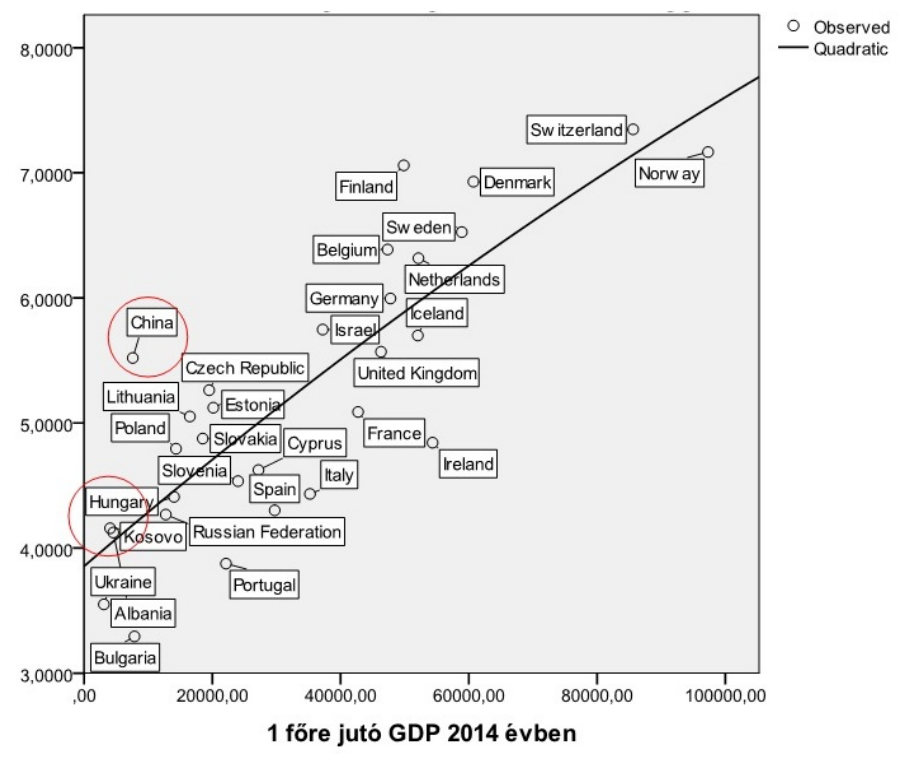

II.2. ábra Elégedettség és a GDP összefüggése

17 Easterlin 1974. 
Az egy före jutó GDP-t hasonlítottam össze az egyes országokban a megkérdezettek elégedettségének átlagával. Az ábra világosan mutatja, hogy az egy före eső GDP növekedésével nő az elégedettség is, azonban a legjobban illeszkedő függvény nem a lineáris függvény, hanem a másodfokú regressziós egyenlet, amelynek a negatív paramétere miatt a GDP, ha elér egy bizonyos értéket, akkor már nem nő az elégedettség, hanem csökkenni fog.

$y=-0.0000000006380 x^{2}+0.00004387 x+3.855$

ahol $\mathrm{y}=$ elégedettség

$\mathrm{x}=\mathrm{GDP}$

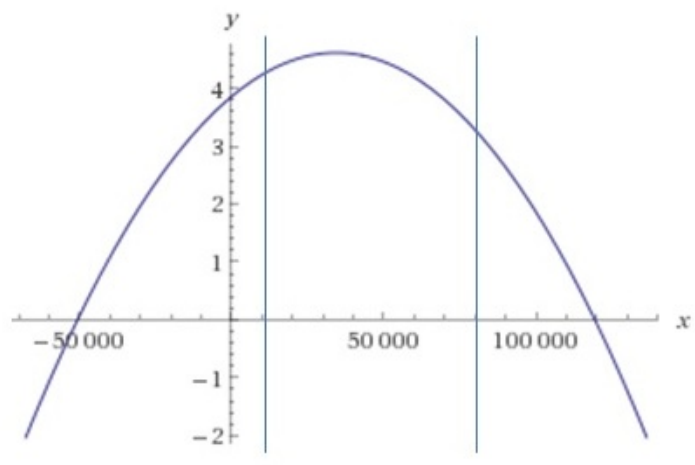

( $x$ from -67615 to 136376 )

II.3. ábra

Ez az ábra jól mutatja, hogy az országok szintjén a gazdasági jólét növekedése egy idő után az elégedettség csökkenésével jár, ezt fejezi ki a másodfokú regressziós függvény negatív együtthatója.

Vagyis adataim alapján azt állapíthatom meg, hogy az Easterlin-paradoxon országok szintjén müködik, tehát igaza van Easterlinnek, szemben az őt bírálók állításaival.

A fenti ábrából az a következtetés vonható le, hogy a kínaiak elégedettebbnek mondják magukat, mint ahogy az országuk fejlettsége (egy före eső GDP) alapján várható lenne. A magyarok tényleges elégedettségének mértéke viszont nem tér el a gazdasági fejlettségből következtethető becsléstől. ${ }^{18}$

18 Easterlin 2001. 


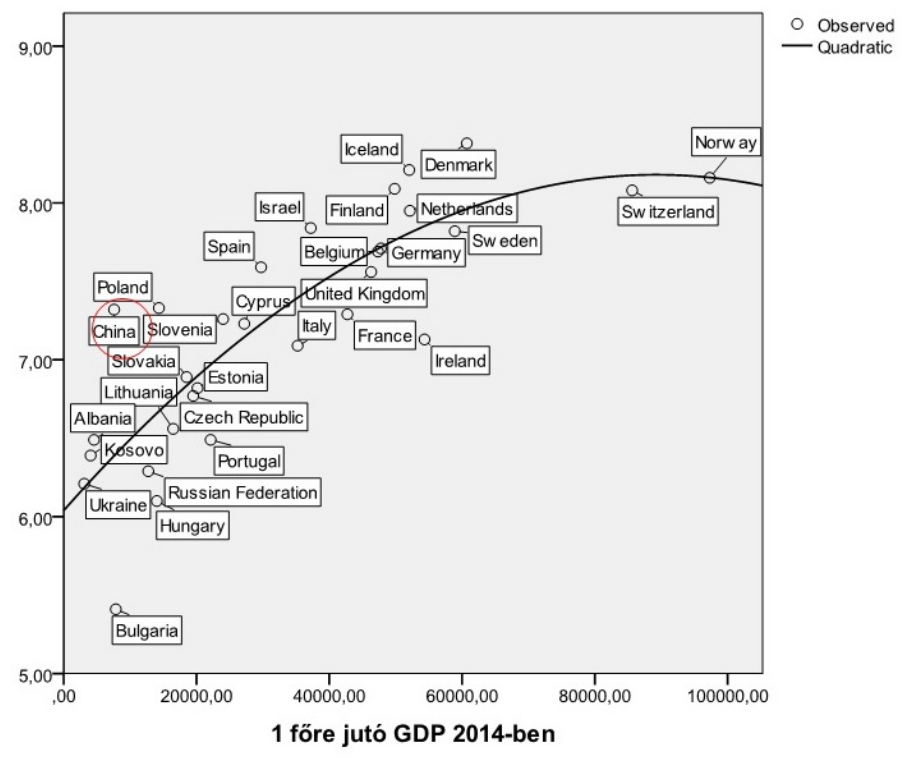

II.4. ábra Boldogság és a GDP összefüggése

Ha az egyének boldogságát össze akarjuk vetni az országuk gazdasági fejlettségével, felhasználva az adott ország GDP mutatóját, akkor egyrészt még szebben rajzolódik ki a Easterlin-paradoxon, vagyis a fejlettség növekedése egy fejlettségi szint után már nem vonja maga után a boldogság növekedését. A boldogság értéke hasonlóan az elégedettséghez a kínaiak esetében lényegesen nagyobb a fejlettségükből következtethető szintnél, a magyaroknál viszont a boldogság lényegesen alatta marad a fejlettségből következtethetőnél.

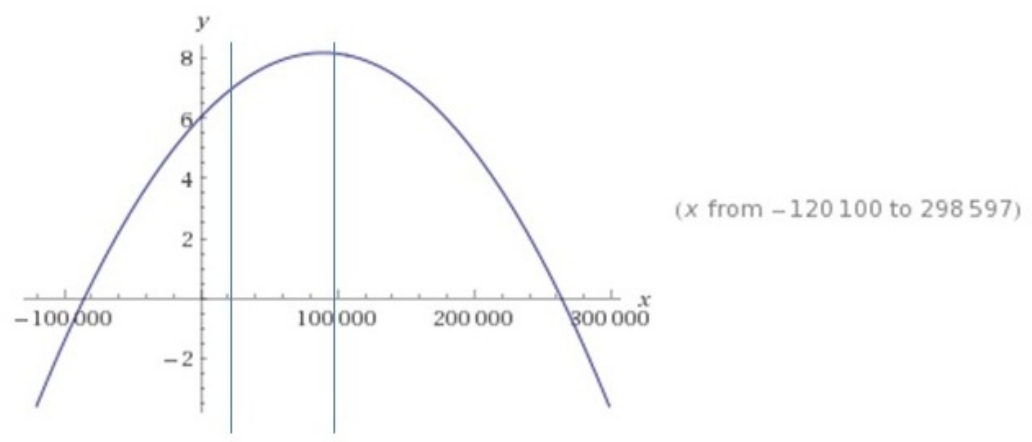

II.5. ábra 


\section{Összefoglalás}

A kutatás eredményei alapján az alábbi megállapításokat tehetjük a kínai emberek elégedettségével és boldogságával kapcsolatban:

A kínai emberek a saját életükkel sokkal elégedettebbek, mint az országéval, annak demokráciájával, a kormány munkájával és gazdasági állapotával. Kínai kísérleti kutatásom szerint a megkérdezettek mostani életükkel sokkal elégedettebbek, mint a magyarok (a különbség 1,13, vagyis több mint egy létrafok), az európai átlagot hibahatáron belül elérik.

A kínai vizsgált személyek különösen kormányuk munkájával elégedettebbek, mint európai társaik (a magyarokénál 2,12, az európai átlagnál 1,74 a különbség a javukra).

A kínaiak átlagos elégedettsége is jelentősen magasabb $(5,52)$, a magyarokénál 1,1-del (egy lépcsőfokkal), az európaiak átlagánál 0,27-tel.

A kínai elégedettség terét a megkérdezettek mostani életével való elégedettség, a kínai kormánnyal való elégedettség, illetve az egészségügy és az oktatás állapotával való elégedettség (ezzel a kettővel a legelégedetlenebbek) három sarokpontja feszíti ki, ami azonban sajátos: ezen belül van egy ún. „ördögkerék”, ennek van egy mozgásban forgó kör/ellipszis aljzata, amit a kormányrúd mozgat, s mutatja a haladás irányát és sebességét.

Az emberek másként élik meg a saját életüket és azokat a területeket, ahol közvetlenül vannak kapcsolatban a társadalommal (egészségügy, oktatás), illetve a rájuk közvetetten ható, a kormányzással szorosan összefüggő, a kormány munkájával, a gazdaság állapotával és a demokrácia müködésével kapcsolatos területeket. Ez a három terület jól elkülönül egymástól, bizonyos szembenállást is mutat (az egyikkel elégedettek nem feltétlenül elégedettek a szembenálló területtel), egy háromszög három csúcspontjaként. Európa 29 országában együttesen nagyon hasonló, lényegében a magyarokéval megegyező konfigurációt mutat.

A kínai kísérleti minta adatai alapján Kína a 12. helyet foglalná el az elégedettség indikátor szerinti sorrendben. A kínaiak saját kormányukkal a legelégedettebbek az összehasonlító sorrendben, de előkelő helyen ítélik meg országuk gazdasági állapotát is. Az egészségügy és az oktatás állapotával a legkevésbé elégedettek, és ez a sorrenden meg is látszik, ezen két területen az utolsó harmadban helyezkednek el.

Minél jobban bíznak a megkérdezettek az emberekben, annál elégedettebbek nemcsak eddigi életükkel, de az ország gazdasági állapotával, a kor- 
mány müködésével, a demokrácia müködésével, az oktatás és az egészségügy állapotával is. Ez a kapcsolat nagyon szoros, a Pearson-féle korreláció 0,829.

A kínai emberek boldogság-indikátorát vizsgálva azt mondhatjuk, hogy a kínai mintába bekerült emberek átlagosan boldogabbak, mint európai társaik.

A boldogság és az elégedettség exponenciális $\left(\mathrm{y}=\mathrm{e}^{\mathrm{x}}\right)$ kapcsolatot mutat. A boldogság független változó az elégedettség indikátor varianciájának $76 \%$-át magyarázza az exponenciális modellben (a lineáris modellben ez 73,9\%)! Ezt úgy lehet értelmezni, hogy minél boldogabb egy ország lakossága, annál elégedettebb is.

Az individualista értékek átalakulóban vannak. Az 1990-es évek második felében elindult reformok átalakították a kínai fogyasztói társadalom magatartásformáit és értékeit, de a fogyasztói civilizáció magatartásnormái és értékei közül nem veszített fontosságából a kínaiakban a boldogság és elé-

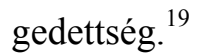

Bár a nyugati demokrácia fogalmaival definiálható demokratikus átalakulás nem zajlott le Kínában, a demokratikus politikai kultúra fejletlenségére és müködésének hiányára pedig több érvet szoktak felhozni a kutatók, illetve többen, többféleképpen próbálták már nevesíteni azokat a sajátos kínai mechanizmusokat, amelyek a modern kínai társadalom átalakulását jellemzik, ${ }^{20}$ mégis, a mindennapi kínai emberek szubjektív jóléte - elégedettsége, boldogsága - hozzájárul a jelenlegi kormányzati rendszer hosszú távú stabilitásához, Kína sajátos politikai rendszerének zavartalan müködéséhez.

19 Kozjek-Gulyás 2016.

20 Bell 2015. 


\section{Néhány oldal a 15 oldalas kérdőívből}

\section{中国人的价值观、生活目标、生活方式 \\ 研究者：Kozjek-Gulyás Anett 安奈特}

世界中心

\section{每线只能选一个答案!}

先请您, 根据性格、特征对比六个国家。请您根据国家特征选择一个国家!

\begin{tabular}{|c|c|c|c|c|c|c|c|}
\hline \multicolumn{2}{|r|}{ 燃 } & 美国 & 法国 & 甸牙利 & 德国 & 俄罗斯 & 中国 \\
\hline 1. & 自由 & & & & & & \\
\hline 2. & 民主 & & & & & & \\
\hline 3. & 充满活力的经济发 & & & & & & \\
\hline 4. & 好的电影 & & & & & & \\
\hline 5. & 好的音乐 & & & & & & \\
\hline 6. & 新时尚 & & & & & & \\
\hline 7. & 社会正义 & & & & & & \\
\hline 8. & 社会保障 & & & & & & \\
\hline 9. & 刑事 & & & & & & \\
\hline 10. & 著名球星 & & & & & & \\
\hline 11. & 企业成功 & & & & & & \\
\hline 12. & 创新思想 & & & & & & \\
\hline 13. & 毒品问题 & & & & & & \\
\hline 14. & 新的科学发现 & & & & & & \\
\hline 15. & 新技术和新设备 & & & & & & \\
\hline 16. & 道德价值 & & & & & & \\
\hline 17. & 艺术价值、美术 & & & & & & \\
\hline 18. & 安全 & & & & & & \\
\hline 19. & 诚实 & & & & & & \\
\hline
\end{tabular}


满意

B1. 总而言之, 您满意现在的生活吗? 请回答问题, “ 00 ”意思是您完全不满意, “10”意思是您完全满意。

完全不满意 00 $01 \quad 02$ $02 \quad 03$ $\begin{array}{lll}04 & 05 & 06\end{array}$ $\begin{array}{lll}07 & 08 & 09\end{array}$ 完全满意 10

B2. 总体而言, 您对中国目前的经济状况的满意度如何?

完全不满意 00 $\begin{array}{lll}01 & 02 & 03\end{array}$ $04 \quad 05 \quad 06$ 完全满意 10

B3. 您对当前中国政府工作的满意度如何?

完全不满意 00 0102 0203 0304 0506 完全满意

B4. 总而言之, 您对中国法律满意度如何?

完全不满意 00 $\begin{array}{lll}01 & 02 & 03\end{array}$

$04 \quad 05 \quad 06$

$\begin{array}{lll}07 & 08 & 09\end{array}$ 完全满意 10

B5. 您对教育的总体状况的看法是什么?

非常不好 $\begin{array}{llllllllll}00 & 01 & 02 & 03 & 04 & 05 & 06 & 07 & 08 & 09\end{array}$ 非常好

B6. 您如何看待医疗现状?

非常不好

00

$\begin{array}{lll}01 & 02 & 03\end{array}$

030

0506

$\begin{array}{lll}07 & 08 & 09\end{array}$ 
自我价值施瓦茨值测试

下面我们描述人的特征。请, 读以下这些特征然后选择这些特征像或 不像您。请回答时用打 “ $\sqrt{ }$ ” 表示最像您

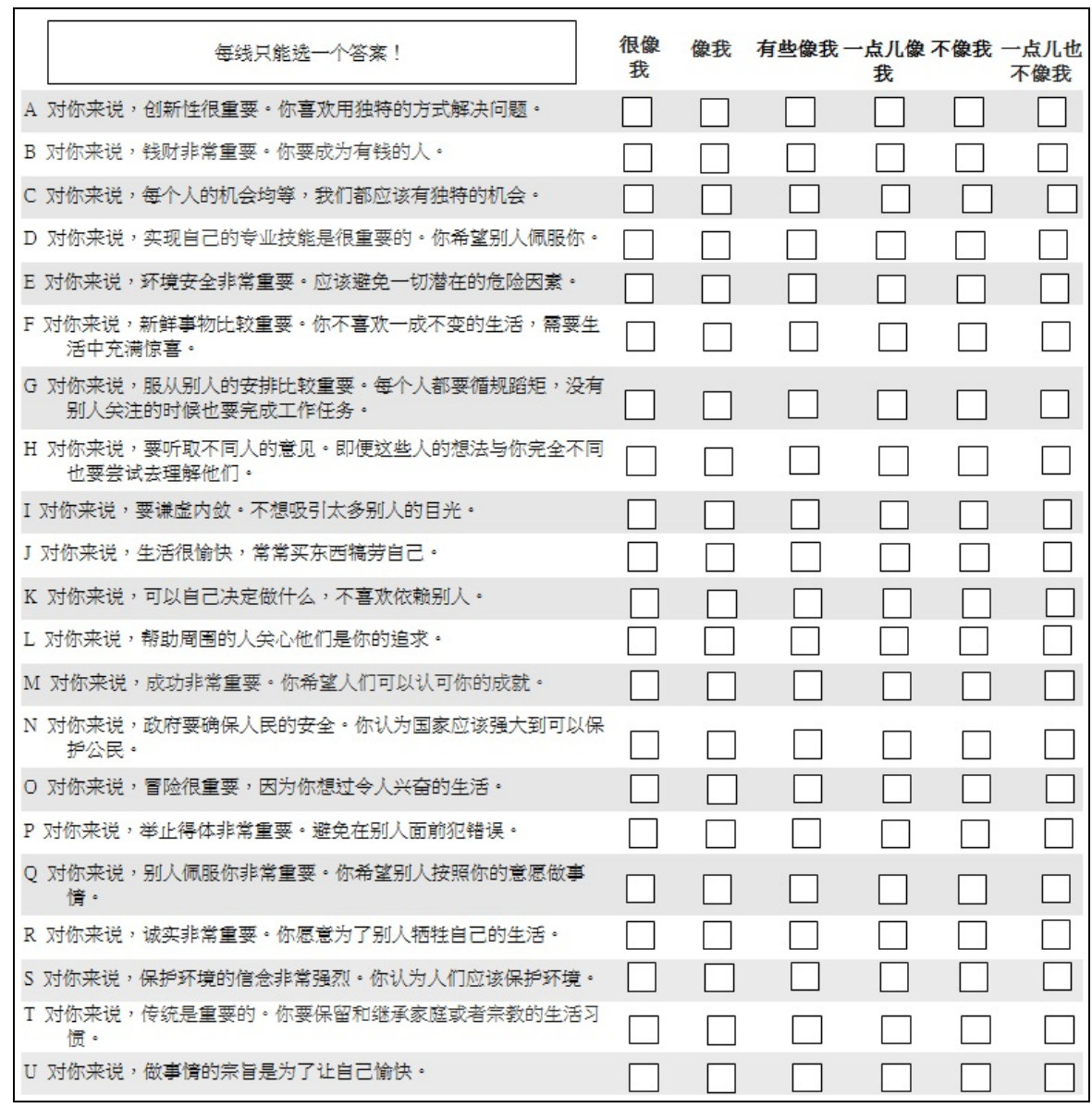




\section{Másodlagos szakirodalom}

Bell, Daniel A. 2015. The China Model Political Meritocracy and the Limits of Democracy. Princeton and Oxford: Princeton University Press.

Easterlin, Richard A. 1974. „Does economic growth improve the human lot? Some empirical evidence." In: Paul A. David - Melvin W. Reder (eds.) Nations and households in Economic Growth: Essays in honor of Moses Abramovitz. New York: Academic Press, 89-125.

Easterlin, Richard 2001. „Income and Happiness: towards a Unified Theory.” The Economic Journal 111/July: 465-484.

Füstös, László - Tárnok, Orsolya 2013. Értékváltozás Magyarországon 1978-2009: Értékváltozás vagy értékválság? Budapest: Present.

Itoh, Fumio (ed.) 1997. China in the Twenty-first Century Politics, Economy, and Society. Tokyo: United Nations University Press.

Ji, Jianjun - Xiaohe Xu - S. Lynne Rich 2002. „Determinants of Family Life Satisfaction in Reforming Urban China." International Journal of Comparative Sociology 43: 169-191.

Inglehart, R. - R. Foa - C. Peterson - C. Welzel 2008. „Development, Freedom and Rising Happiness: A Global Perspective 1981-2006." Perspectives on Psychological Science 3/4: 264-285.

Jagodzinski, W. 2010. „Economic, Social, and Cultural Determinants of Life Satisfaction: Are there Differences Between Asia and Europe?" Social Indicators Research 97/1: 85-104.

Kozjek-Gulyás, Anett 2016. „Az értékek szerepe és azok változása a mai Kínában.” Mühely XXXIX. évfolyam, 5-6:45-49.

Naughton, Barry 2006. The Chinese Economy: Transitions and Growth. Cambridge, Mass.: The MIT Press.

Pei, Minxin 2008. China's Trapped Transition. Cambridge, Mass.: Harvard University Press.

Shambaugh, David 2014. China at the Crossroads: Ten Major Reform Challenges. Washington: Brookings Institute. [Online elérhetőség: https://www.brookings.edu/ wp-content/uploads/2016/06/01-china-crossroads-reform-challenges-shambaugh-b.pdf. Utolsó megtekintés: 2017.12.27.]

Song, Lina- Simon Appleton 2008. Life satisfaction in Urban China: Components and Determinants. IZA Discussion Paper No. 3443. [Online elérhetőség: http://ftp.iza.org/ dp3443.pdf. Utolsó megtekintés: 2017.12.27.]

Steele, Liza G. - Scott M. Lynch 2014. „The Pursuit of Happiness in China: Individualism, Collectivism, and Subjective Well-Being during China's Economic and Social Transformation." Social Indicators Research 114/2: 441-451. 